\title{
Crystal Structure and Biological Evaluation of Two Novel Organic-Inorganic Hybrid Materials as Antitumor Agents in the Treatment of Liver Cancer
}

\author{
Bao-Hua Song, ${ }^{1}$ Chen $\mathrm{Li}^{1}{ }^{1}$ and Gui-Feng An $\mathbb{D}^{1,2}$ \\ ${ }^{1}$ Inner Mongolia University for Nationalities, Tongliao, Inner Mongolia, China \\ ${ }^{2}$ The First Affiliated Hospital of Inner Mongolia University for Nationalities, Tongliao, Inner Mongolia, China
}

Correspondence should be addressed to Gui-Feng An; anguifeng1224@163.com

Received 2 April 2018; Accepted 30 April 2018; Published 27 May 2018

Academic Editor: Henryk Kozlowski

Copyright (C) 2018 Bao-Hua Song et al. This is an open access article distributed under the Creative Commons Attribution License, which permits unrestricted use, distribution, and reproduction in any medium, provided the original work is properly cited.

Two novel organic-inorganic hybrid materials $\left\{(\mathrm{Hbiz})_{6}\left[\mathrm{As}^{\mathrm{III}}{ }_{2} \mathrm{As}^{\mathrm{V}} \mathrm{Mo}^{\mathrm{VI}}{ }_{18} \mathrm{O}_{62}\right]\right\} \cdot \mathrm{H}_{2} \mathrm{O}$ (1, biz= benzimidazole) and (dim) $\left[\mathrm{As}^{\mathrm{III}}{ }_{2} \mathrm{As}^{\mathrm{V}} \mathrm{Mo}^{\mathrm{VI}}{ }_{18} \mathrm{O}_{62}\right][2, \mathrm{dim}=1,6$-bis(imidazol)hexane] have been successfully obtained by using the molybdenum arsenate and different $\mathrm{N}$ donor organic compounds and determined through $\mathrm{X}$-ray single-crystal diffraction technique. The in vitro cytotoxicity of compounds $\mathbf{1}$ and $\mathbf{2}$ was then investigated against three human liver tumor cell lines (SMMC7721, Bel-7402, and MHCC97) by MTT assay. It was found that the two compounds showed potent use as antitumor agents against the aforementioned cell lines.

\section{Introduction}

Despite remarkable progress in the evolution of biological medicine field and understanding of the origin of the de diseases, the scientists fail to obtain effective methods for treating some diseases such as cancer. Nowadays, it has been widely recognized that cancer is one of the most serious threat to the health of people worldwide which could cause millions of deaths every year [1]. In spite of great efforts currently being devoted to the creation of therapeutic tools, current effective therapeutic is limited to chemotherapy, which is the dominant treatment method. In this case, the creation of effective chemotherapy drugs with low cost, high selectivity, undesirable side effects, and low cytotoxicity is of high importance $[2,3]$. The cancer cell resistance to anticancer agents and the toxicity of modern chemotherapy make the sciences worldwide search for new drugs and cure methods for such an insidious disease [4].

The design and fabrication of inorganic-organic hybrid materials have drawn much interest in the last twenty years not only for their variable building block but also the excellent properties that inherit from the both organic and inorganic parts, which also leads the function as function materials in many important areas such as fluorescence and guest-dependent sorption [5-7]. Recent literatures have demonstrated that the $\mathrm{N}$ donor imidazole ligand is a good coordinating ligand in the synthesis of organic-inorganic hybrid materials, which may adopt many different types of coordinating modes, for instance cocrystal, monodentate chelating, and mutidentate bridging in the anti-anti, syn-syn, and syn-anti arrangement $[8,9]$. So far, many metal-imidazole organic-inorganic hybrid materials have been designed and characterized widely. In this work, two novel organicinorganic hybrid materials $\left\{(\mathrm{Hbiz})_{6}\left[\mathrm{As}_{2} \mathrm{Mo}_{18} \mathrm{O}_{62}\right]\right\} \cdot \mathrm{H}_{2} \mathrm{O}$ $(\mathbf{1}$, biz = benzimidazole $)$ and $(\operatorname{dim})\left[\mathrm{As}^{\mathrm{III}}{ }_{2} \mathrm{As}^{\mathrm{V}} \mathrm{Mo}^{\mathrm{VI}}{ }_{18} \mathrm{O}_{62}\right]$ (2, $\operatorname{dim}=1,6$-bis(imidazol)hexane) have been successfully obtained by using the molybdenum arsenate and different $\mathrm{N}$ donor compounds (Figure 1) under hydrothermal conditions and their corresponding antitumor performance was subsequently studied.

\section{Experimental}

2.1. Instruments and Chemicals. The Rigaku D/MAX $2500 \mathrm{~V}$ diffractometer was used to collect the Powder X-ray diffraction (PXRD) curves. An Oxford Xcalibur E diffractometer was 
<smiles>c1ccc2[nH]cnc2c1</smiles><smiles>c1cn(CCCCCn2ccnc2)cn1</smiles>

FIGURE 1: Schematic representation of the benzimidazole and 1,6bis(imidazol)hexane organic compounds used in this research.

employed to collect the single crystal X-ray diffraction data. Perkin-Elmer model 240C instrument was employed to obtain the element analyses $(\mathrm{C}, \mathrm{H}$, and $\mathrm{N})$ results. All the chemicals in this study were commercially available and used as received.

SMMC7721, Bel-7402, and MHCC97 human liver cancer cells used in this work were commercially available from the Beijing National Institute for the Control of Biological and Pharmaceutical Products (China).

2.2. The Preparation Methods of Compounds 1 and 2. biz (0.15 mmol), $\mathrm{As}_{2} \mathrm{O}_{3}(0.8 \mathrm{mmol}), \mathrm{Na}_{2} \mathrm{MoO}_{4} \cdot 2 \mathrm{H}_{2} \mathrm{O}(2 \mathrm{mmol})$, and $\mathrm{H}_{2} \mathrm{O}(18 \mathrm{~mL})$ were mixed in a $25 \mathrm{~mL}$ of Teflon-lined stainless steel vessel, kept at $140^{\circ} \mathrm{C}$ for 72 hours. After the reaction time is out, the system is left until the oven return to room temperature. The black block-shape crystals were collected, cleaned with flowing deionized water, and air dried. Yield: $36 \%$ (based on biz ligand). Elemental analysis for compound $1\left(\mathrm{C}_{42} \mathrm{H}_{30} \mathrm{~N}_{12} \mathrm{As}_{2} \mathrm{Mo}_{18} \mathrm{O}_{63}\right)$ : C, 14.01; $\mathrm{H}, 0.82$; N, 4.61\%. Calculated: C, $14.05 ; \mathrm{H}, 0.84 ; \mathrm{N}, 4.69 \%$.

$\operatorname{dim}(0.2 \mathrm{mmol}), \mathrm{As}_{2} \mathrm{O}_{3}(0.5 \mathrm{mmol}), \mathrm{Na}_{2} \mathrm{MoO}_{4} \cdot 2 \mathrm{H}_{2} \mathrm{O}$ ( $1 \mathrm{mmol})$, and $\mathrm{H}_{2} \mathrm{O}(18 \mathrm{~mL})$ were mixed in a $25 \mathrm{~mL}$ of Teflonlined stainless steel vessel, kept at $140^{\circ} \mathrm{C}$ for 72 hours. After the reaction time is out, the system is left until the oven returns to room temperature. The black block-shape crystals were collected, cleaned with flowing deionized water, and air dried. Yield: 36\% (based on dim ligand). Elemental analysis for compound $2\left(\mathrm{C}_{11} \mathrm{H}_{16} \mathrm{~N}_{12} \mathrm{As}_{2} \mathrm{Mo}_{9} \mathrm{O}_{31}\right): \mathrm{C}, 9.03 ; \mathrm{H}, 0.84 ; \mathrm{N}$, 9.81\%. Calculated: C, 8.99; H, 0.93; N, 9.80\%.

2.3. Structural Analysis through the X-Ray Diffraction Technique. A graphite monochromatized Mo radiation ( $0.71073 \AA$ ̊) equipped Oxford Xcalibur E diffractometer with was used to collect the reflection data of $\mathbf{1}$ and $\mathbf{2}$ at $298 \mathrm{~K}$. The direct method in the XS program was used to get the initial structural modes and the least-squares method in XL program was used to refine the structural models [10]. All the $\mathrm{H}$ atoms were poisoned at their ideal locations and refined using the AFIX commands according to their $\mathrm{C}$ atoms attached, and all nonhydrogen atoms in the two structures were treated anistropically. Table 1 shows the crystal data and the structure refinements. Crystal data and structural refinement parameters for compounds $\mathbf{1}$ and $\mathbf{2}$ are shown in Table 1.

2.4. Antitumor Activity. The RPMI 1460 medium was employed to grow the three human liver cancer cells (SMMC7721, Bel-7402, and MHCC97). Before the cell growth, the medium was supplemented with $100 \mu \mathrm{g} / \mathrm{mL}$ streptomycin, $100 \mu \mathrm{g} / \mathrm{mL}$ penicillin, and $10 \%$ fetal calf serum. A humidified incubator with a $5 \% \mathrm{CO}_{2}$ atmosphere was used to incubate the system at $310 \mathrm{~K}$. Subsequently, the
TABle 1: Crystal data and structure refinements for compounds 1 and 2 .

\begin{tabular}{|c|c|c|}
\hline & 1 & 2 \\
\hline Formula & $\mathrm{C}_{42} \mathrm{H}_{30} \mathrm{As}_{2} \mathrm{Mo}_{18} \mathrm{~N}_{12} \mathrm{O}_{63}$ & $\mathrm{C}_{11} \mathrm{H}_{16} \mathrm{As}_{2} \mathrm{Mo}_{9} \mathrm{~N}_{4} \mathrm{O}_{31}$ \\
\hline$M_{\mathrm{r}}$ & 3587.54 & 1713.58 \\
\hline Crystal system & Triclinic & Orthorhombic \\
\hline Space group & P-1 & $\mathrm{Cmcm}$ \\
\hline$a(\AA)$ & $14.192(3)$ & $22.937(2)$ \\
\hline$b(\AA)$ & $14.417(3)$ & $17.9135(16)$ \\
\hline$c(\AA)$ & $23.228(4)$ & $20.0763(17)$ \\
\hline$\alpha\left(^{\circ}\right)$ & $91.336(2)$ & 90 \\
\hline$\beta\left(^{\circ}\right)$ & $101.346(2)$ & 90 \\
\hline$\gamma\left({ }^{\circ}\right)$ & $112.992(2)$ & 90 \\
\hline$V\left(\AA^{3}\right)$ & $4263.2(13)$ & $8249.1(12)$ \\
\hline$Z$ & 2 & 8 \\
\hline$D_{\text {calc }}\left(\mathrm{g} \cdot \mathrm{cm}^{-3}\right)$ & 2.795 & 2.760 \\
\hline $\begin{array}{l}\text { Crystal size } \\
\left(\mathrm{mm}^{3}\right)\end{array}$ & $0.32 \times 0.16 \times 0.23$ & $0.26 \times 0.26 \times 0.26$ \\
\hline $\begin{array}{l}\mu(\mathrm{Mo} \mathrm{K} \alpha) \\
\left(\mathrm{mm}^{-1}\right)\end{array}$ & 3.435 & 4.331 \\
\hline$\theta$ range $\left({ }^{\circ}\right)$ & 2.24 to 28.34 & 2.274 to 28.272 \\
\hline $\begin{array}{l}\text { Reflections } \\
\text { collected }\end{array}$ & 39782 & 38287 \\
\hline $\begin{array}{l}\text { Number of } \\
\text { unique data } \\
(R(\text { int }))\end{array}$ & 21258 & 5383 \\
\hline $\begin{array}{l}\text { Number of data } \\
\text { with } I \geq 2 \sigma(I)\end{array}$ & 16747 & 4624 \\
\hline$R_{1}$ & 0.0712 & 0.0658 \\
\hline$\omega R_{2}$ (all data) & 02186 & 0.2080 \\
\hline CCDC & 1810739 & 1810740 \\
\hline
\end{tabular}

synthesized compounds were dissolved in DMSO at $1 \mathrm{mM}$ immediately before use and diluted just before the addition to the cell culture. After incubation of cells for up to $96 \mathrm{~h}$, the medium was removed from each cell and $15 \mu \mathrm{L}$ of MTT $(0.5 \mathrm{mg} / \mathrm{mL})$ solution was added after the supernatant was removed carefully with the addition of another $100 \mu \mathrm{L}$ of dimethyl sulfoxide. The 96-well plate was shaken for $5 \mathrm{~min}$, and then the cell viability was detected. The $\mathrm{IC}_{50}$ values were determined by plotting the percentage viability versus concentration on a logarithmic graph and reading of the concentration at which $50 \%$ of cells viable relative to the control. Each experiment was repeated at least three times to get the mean values.

\section{Results and Discussion}

3.1. Molecular Structure. An X-ray single crystalline structural investigation demonstrates that compound $\mathbf{1}$ is built from Wells-Dawson polyoxoanion $\left[\mathrm{As}_{2} \mathrm{Mo}_{18} \mathrm{O}_{62}\right]^{6-}$ (signed as $\left.\mathrm{As}_{2} \mathrm{Mo}_{18}\right)$, six free ligands $\mathrm{Hbiz}^{+}$, and water molecule (Figure 2(a)). Two $\left[\alpha-\mathrm{AsMo}_{9} \mathrm{O}_{31}\right]^{3-}$ units are connected with each other through the corner-sharing with elimination of six oxygen atoms to shape the classical Wells-Dawson polyoxoanion, which has only two structurally independent kinds of tungsten (12 equatorial and six polar) with $D_{3 h}$ symmetrical point group. The calculation results as revealed by the software bond valence sum (BVS) calculations confirm that all Mo centers show VI oxidation state. The 


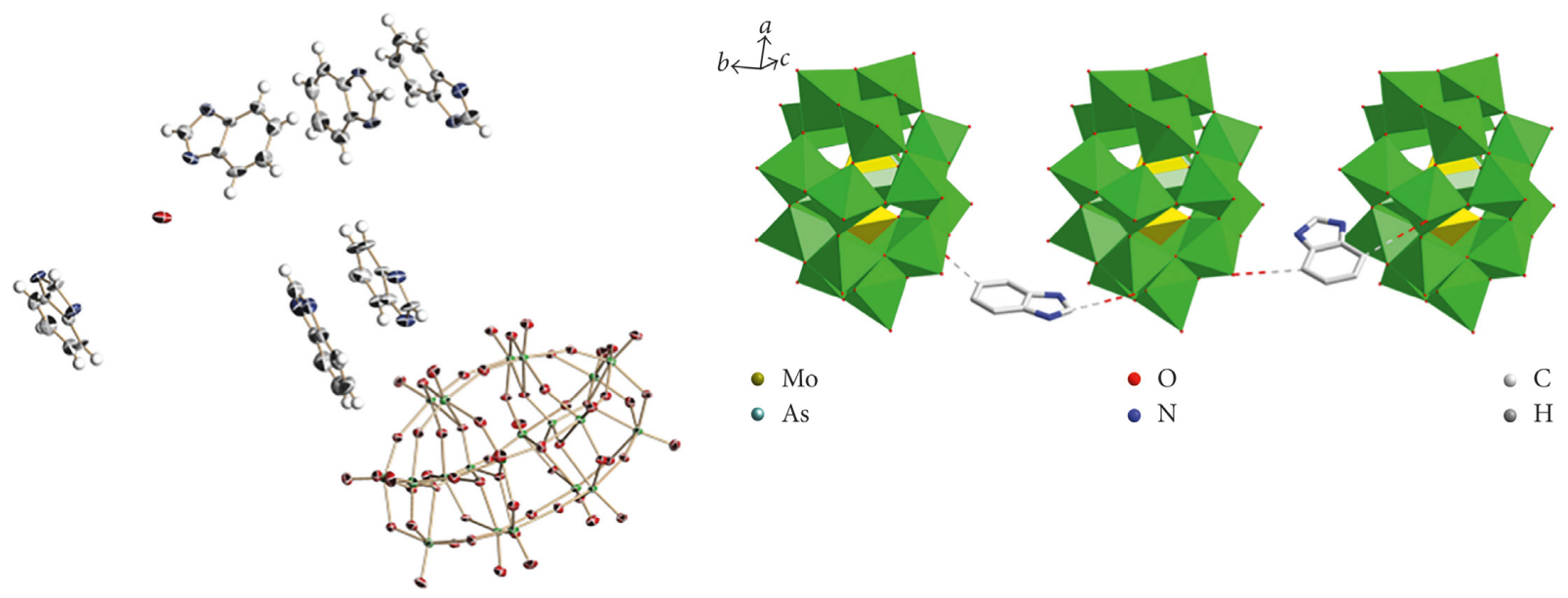

(a)

(b)

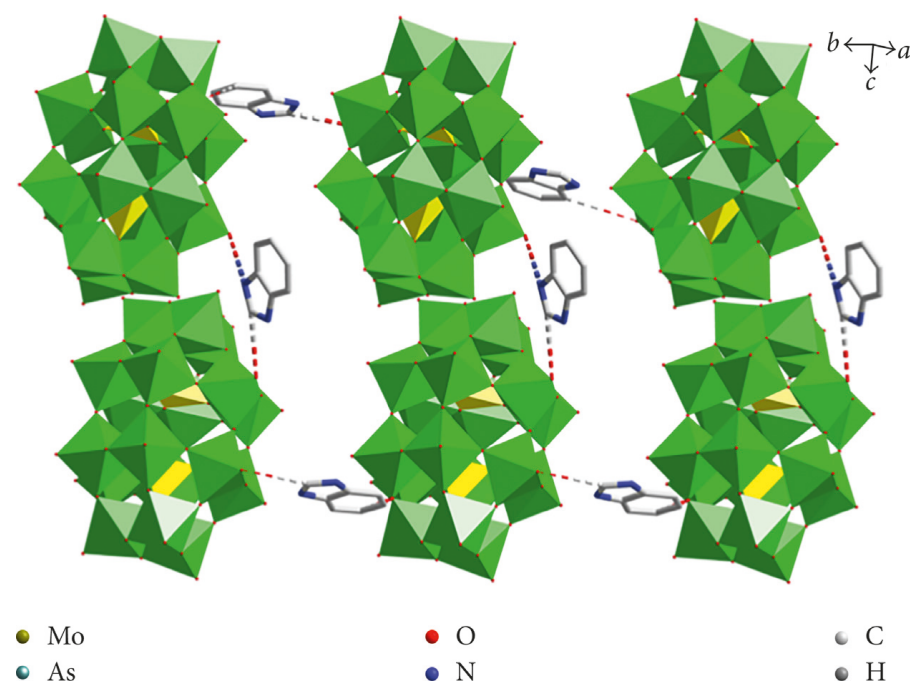

(c)

FIGURE 2: (a) An ORTEP drawing for the molecular unit of $\mathbf{1}$ in 50\% thermal ellipsoids; (b) a drawing with polyhedral and ball-stick pattern for the one-dimensional chain in complex 1 by H-bonds; (c) a picture showing the H-bond interaction between the $2 \mathrm{D}$ layers.

coordination surroundings of Mo atoms could be regarded as a $\left\{\mathrm{MoO}_{6}\right\}$ octahedron with the $\mathrm{Mo}-\mathrm{O}$ bond lengths ranging from 1.679(1)-1.710(1) $\AA$ for edge oxygen donor sites, $1.891(4)-1.917(4) \AA$ for $\mu_{2}$-associated oxygen donor sites, and 2.369(3)-2.412(2) $\AA$ for $\mu_{3}$-associated oxygen donor sites, which are comparable to the values reported in the literature. In contrast, each $\mathrm{As}_{2} \mathrm{Mo}_{18}$ polyoxoanion is coordinating to six free biz ligands by hydrogen bonds along the $a$-axis to lead to the formation of a novel 1-D chain (Figure 2(b)). It is interesting that these ligands further connected with the POMs formed a 2D-layer through hydrogen bonds, and the acceptor-donor distance is $3.262 \AA$ (Figure $2(\mathrm{c})$ ).

$\mathrm{X}$-ray crystal structure determination illuminates that the as-prepared title complex $\mathbf{2}$ is built from Wells-Dawson polyoxoanion $\left[\mathrm{As}_{2} \mathrm{Mo}_{18} \mathrm{O}_{62}\right]^{6-}$ (abbreviated to $\mathrm{As}_{2} \mathrm{Mo}_{18}$ ), two As caps and one ligand dim. Two $\left[\alpha-\mathrm{AsMo}_{9} \mathrm{O}_{31}\right]^{3-}$ units are connected with each other through the corner-sharing with elimination of six oxygen atoms to shape the classical Wells-Dawson polyoxoanion, which has only two structurally independent kinds of tungsten (12 equatorial and six polar) with $D_{3 h}$ symmetrical point group. The calculation results as revealed by the software bond valence sum (BVS) calculations confirm that all Mo centers show VI oxidation state. All the six coordinated Mo atoms reveal a $\left\{\mathrm{MoO}_{6}\right\}$ octahedral surrounding with the Mo-O bond lengths ranging from 1.679(1)-1.710(1) $\AA$ for the edge O donor sites, $1.891(4)-1.917(4) \AA$ for $\mu_{2}$-complexing $\mathrm{O}$ donor sites, and 2.369(3)-2.412(2) $\AA$ for $\mu_{3}$-complexing O donor sites, which are comparable to the values reported in the literature. In addition, each $\mathrm{As}_{2} \mathrm{Mo}_{18}$ polyoxoanion is coordinating to the free dim ligands by hydrogen bonds along the $a$-axis to form an novel 1-D chain (Figure 3(a)). It is interesting that these ligands further connected with the POMs formed a 2D-layer through hydrogen bonds (Figure 3(b)).

3.2. PXRD Patterns. To check the purity of the prepared two compounds, their corresponding power X-ray diffractions were collected at room temperature using their grounded samples. As shown in Figure 4, the peaks in the PXRD curves 


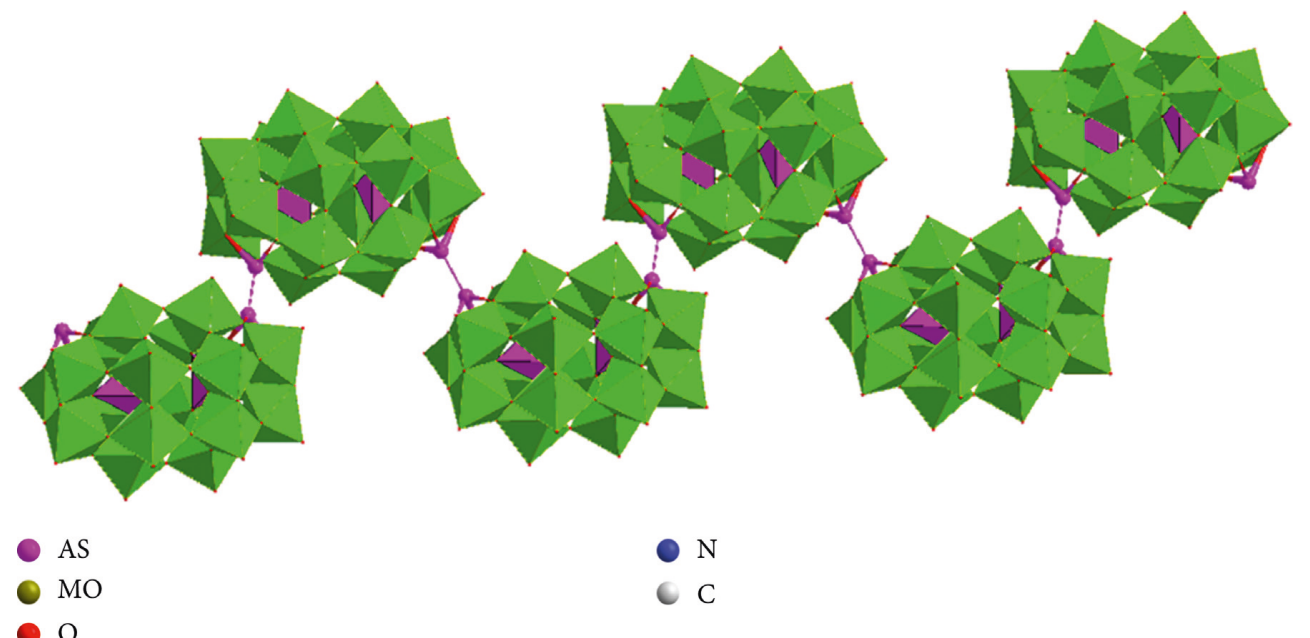

(a)

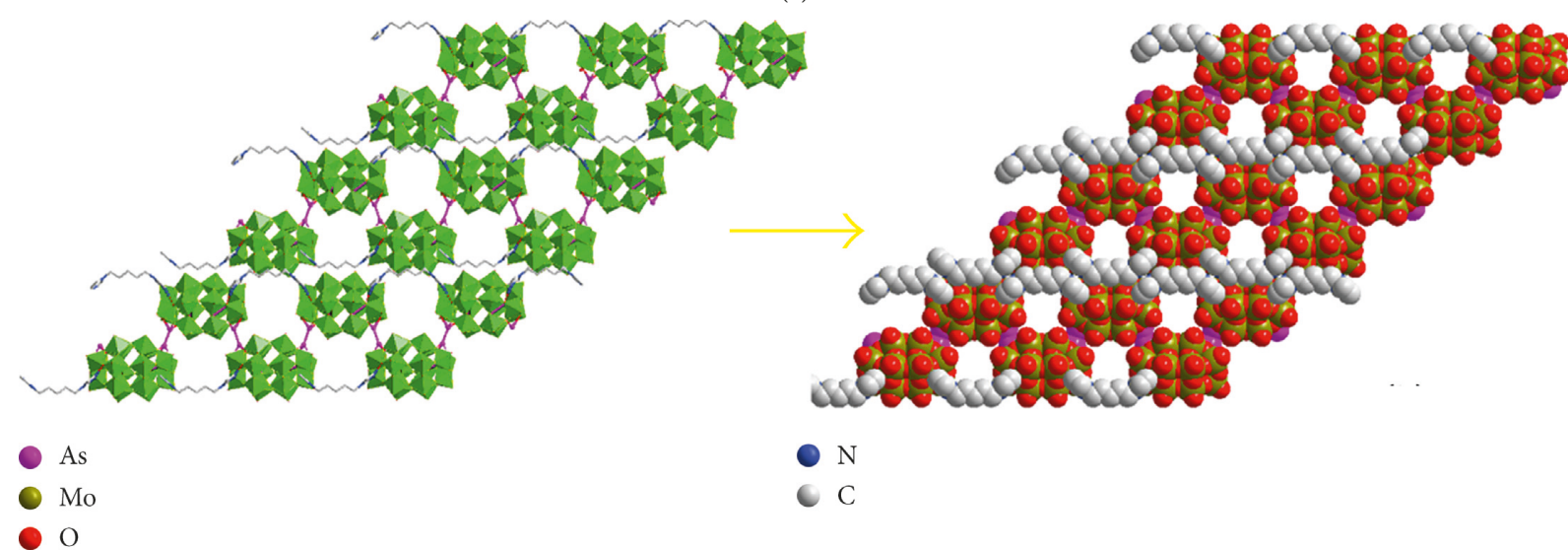

(b)

FIGURE 3: (a) The picture with ball-stick and polyhedral fashion shows the 1D chain of 2 by hydrogen bonds; (b) 2D layered framework of 2 formed by hydrogen bonds.

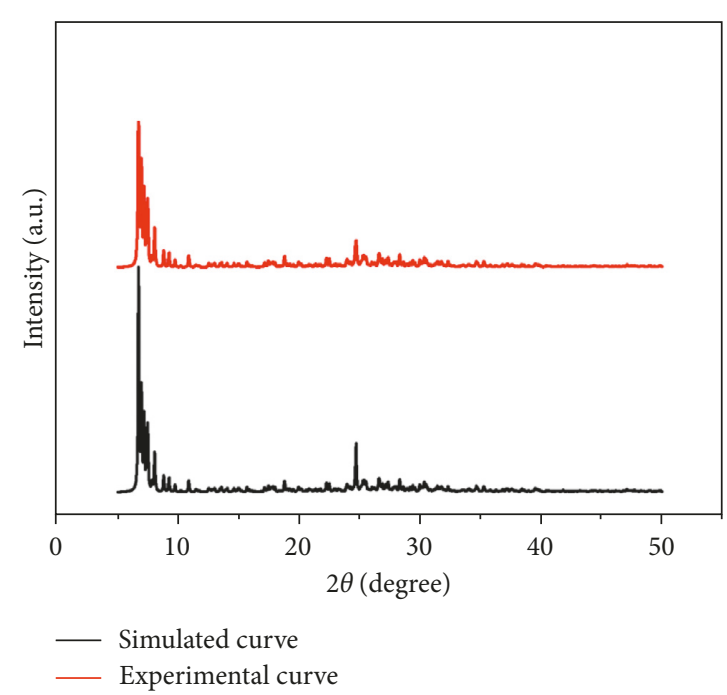

(a)

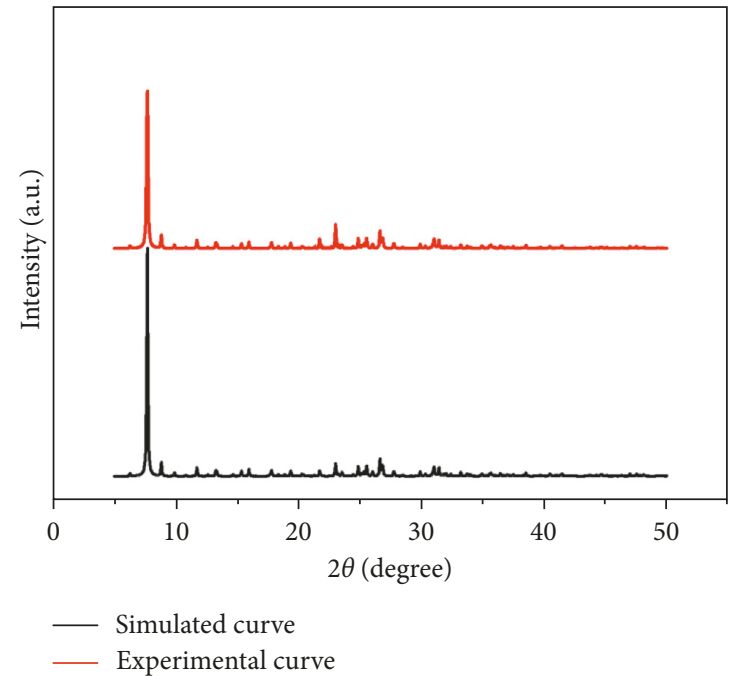

(b)

FIgure 4: The PXRD patterns for 1 (a) and 2 (b). 
TABle 2: Antiproliferative activity $\mathrm{IC}_{50}(\mu \mathrm{M})$ of compounds 1 and 2 .

\begin{tabular}{lccc}
\hline Compounds & \multicolumn{3}{c}{$\mathrm{IC}_{50}(\mu \mathrm{M})^{\mathrm{a}}$} \\
\hline $\mathbf{1}$ & SMMC7721 & Bel-7402 & MHCC97 \\
$\mathbf{2}$ & $45.6 \pm 2.1$ & $49.2 \pm 1.9$ & $62.1 \pm 1.2$ \\
Doxorubicin $^{\mathrm{b}}$ & $50.3 \pm 1.8$ & $45.8 \pm 2.1$ & $59.5 \pm 2.2$ \\
\hline
\end{tabular}

${ }^{a}$ Drug concentration required to reduce cancer cell growth by $50 \%$; ${ }^{b}$ the anticancer drug doxorubicin was chosen as the positive control.

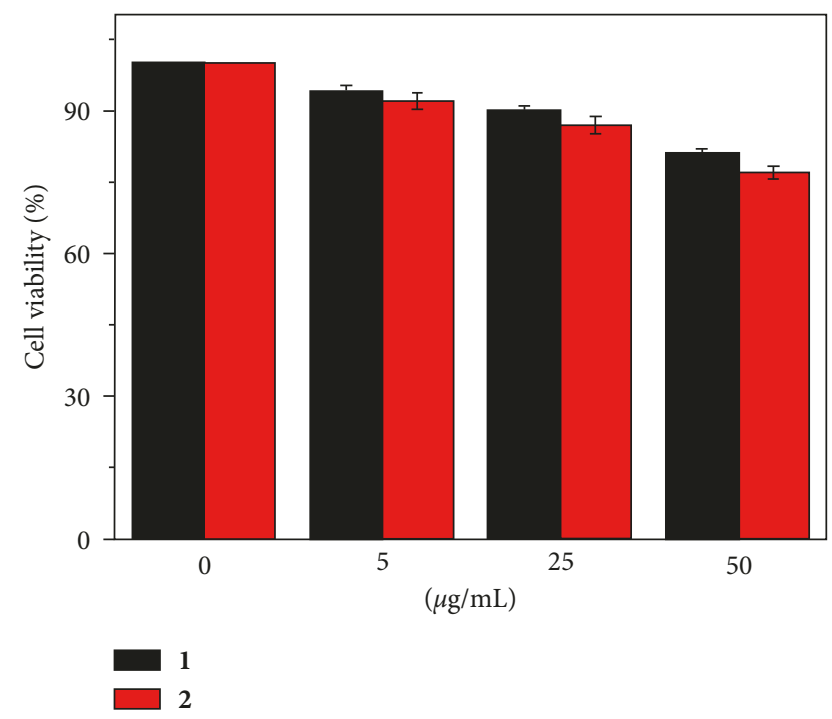

FIGURE 5: Cell viabilities of the oral epidermal cells after incubation with $\mathbf{1}$ and $\mathbf{2}$ at different concentrations.

are in good match with the simulated ones from the crystal data, revealing their phase purity to some extent. The slight difference of some peak intensities between the calculated one and the simulated one might be due to the preferred orientation of the crystal faces.

\subsection{In Vitro Cytotoxicity Study against the Cancer Cells.} Three human liver cancer cells (MHCC97, Bel-7402, and SMMC7721) were used to access the cancer cell growth inhibition activity for the two new metal-organic coordination complexes. The exposure time was set to $48 \mathrm{~h}$, and the drug doxorubicin (DOX) was employed as the reference control with its antiproliferative effects compared to those of the two complexes. DMSO was used to dissolve the as-prepared two complexes at the concentration level of $1 \mathrm{mM}$, which need to be diluted just before the addition to the cell culture.

The data, which show the values for three times of separated experiments carried out in duplicate, are represented in the form of means \pm SEM and are shown in Table 2. A descending order could be observed for the antiproliferative activity of the test complexes toward each type of the tumor cell lines used, which might be ascribed to the measured concentration required to reduce cancer cell proliferation by $50 \%\left(\mathrm{IC}_{50} \mu \mathrm{M}\right)$. From the results above, we can conclude that compounds $\mathbf{1}$ and $\mathbf{2}$ demonstrate comparable growth inhibition activity toward the three tumor cell lines $\left(\mathrm{IC}_{50}=45-62 \mu \mathrm{M}\right)$ with the reference drug DOX, which illuminate their potential use as anticancer drugs.

In order to explore the cytotoxicity of the two compounds toward the human normal cell in vitro, oral epidermal cells (normal cells) were chosen to incubate with $\mathbf{1}$ and 2 under different concentrations $\left(0-50 \mu \mathrm{g} \cdot \mathrm{mL}^{-1}\right)$ for $24 \mathrm{~h}$. As shown in Figure 5, the cell viabilities all remained above $70 \%$ even at a concentration of $50 \mu \mathrm{g} \cdot \mathrm{mL}^{-1}$ of $\mathbf{1}$ and 2 , so the as-prepared two new metals showed low cytotoxicity in the oral epidermal cells.

\section{Conclusion}

The results indicate that complex 1 contains six free ligands biz and one $\left[\mathrm{As}_{2} \mathrm{Mo}_{18} \mathrm{O}_{62}\right]^{6-}$ cluster in the molecular lattice, which is further connected with each other to make up a $2 \mathrm{D}$ supramolecular structure, while complex 2 consists of one free dim ligand and one $\left[\mathrm{As}_{2} \mathrm{Mo}_{18} \mathrm{O}_{62}\right]^{6-}$ cluster in the molecular lattice and demonstrates a $2 \mathrm{D}$ supramolecular structure formed by hydrogen bonds. The in vitro cytotoxicity experiments demonstrate that as-prepared compounds 1 and 2 revealed potent cytotoxicity toward the three human liver tumor cell lines (SMMC7721, Bel-7402, and MHCC97) as similar to that of the reference drug, which also indicates their potential use as antitumor drugs.

\section{Data Availability}

Crystallographic data for the structures reported in this manuscript have been deposited in the Cambridge Crystallographic Data Centre under the CCDC numbers 1810739 (compound 1) and 1810740 (compound 2). Copies of these data can be obtained free of charge from http://www.ccdc. cam.ac.uk/data_request/cif.

\section{Conflicts of Interest}

The authors declare that they have no conflicts of interest.

\section{Acknowledgments}

Grant from the Natural Science Foundation of Inner Mongolia (2017MS(LH)0819) is greatly acknowledged.

\section{References}

[1] X. Du, Z. Shi, Z. Peng et al., "Acetoacetate induces hepatocytes apoptosis by the ROS-mediated MAPKs pathway in ketotic cows," Journal of Cellular Physiology, vol. 232, no. 12, pp. 3296-3308, 2017.

[2] Y. Song, N. Li, J. Gu et al., " $\beta$-Hydroxybutyrate induces bovine hepatocyte apoptosis via an ROS-p38 signaling pathway," Journal of Dairy Science, vol. 99, no. 11, pp. 9184-9198, 2016.

[3] X. Sun, X. Yuan, L. Chen et al., "Histamine induces bovine rumen epithelial cell inflammatory response via $\mathrm{NF}-\kappa \mathrm{B}$ pathway," Cell Physiology Biochemistry, vol. 42, no. 3, pp. 1109-1119, 2017.

[4] X. Du, Y. Zhu, Z. Peng et al., "High concentrations of fatty acids and $\beta$-hydroxybutyrate impair the growth hormone-mediated 
hepatic $\mathrm{JAK}_{2}-\mathrm{STAT}_{5}$ pathway in clinically ketotic cows," Journal of Dairy Science, vol. 101, no. 4, pp. 1-12, 2018.

[5] J. Li, X. H. Ji, and J. T. Li, "Two new inorganic anions directed $\mathrm{Zn}$ (II)-tetrazole frameworks: syntheses, structures and photoluminescent properties," Journal of Molecular Structure, vol. 1147, pp. 22-25, 2017.

[6] J. Li and J. T. Li, "A luminescent porous metal-organic framework with Lewis basic pyridyl sites as a fluorescent chemosensor for TNP detection," Inorganic Chemistry Communications, vol. 89, pp. 51-54, 2018.

[7] W. Gao, F. Liu, X. M. Zhang, J. P. Liu, and Q. Y. Gao, "Four 3D coordination polymers based on layers with single syn-anti carboxylate bridges: synthesis, structures, and magnetic properties," RSC Advance, vol. 8, no. 25, pp. 14101-14108, 2018.

[8] D. Chen, Y. Zhong, C. Zhang, D. Xu, and Z. Lin, "Dual-ligand approach for the solvent-free synthesis of indium-based coordination polymers," Inorganic Chemistry Communications, vol. 92, pp. 74-77, 2018.

[9] P. Köse Yaman and O. Z. Yeşilel, "Hydrothermal synthesis and characterization of cobalt(II), nickel(II) and zinc(II) coordination polymers with $2,2^{\prime}$-dimethylglutarate and 1,2-bis(4-pyridyl)ethane," Polyhedron, vol. 148, pp. 189-194, 2018.

[10] G. M. Sheldrick, "Crystal structure refinement with SHELXL," Acta Crystallographica Section C-Structural Chemistry, vol. 71, no. 1, pp. 3-8, 2015. 

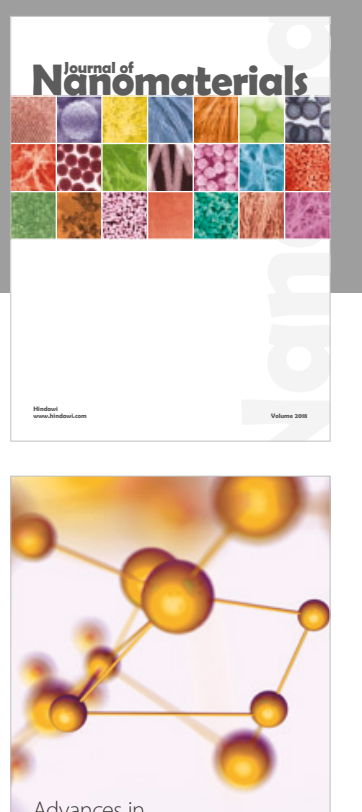

Physical Chemistry
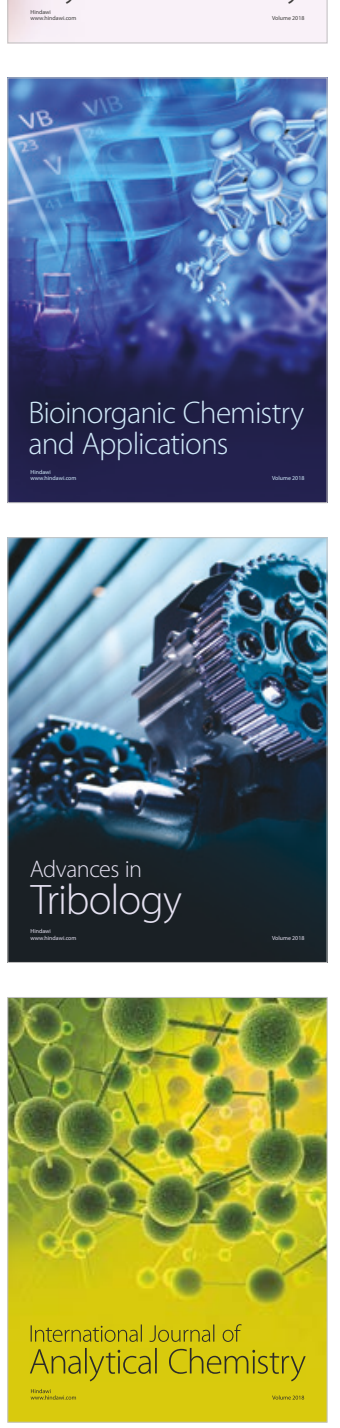

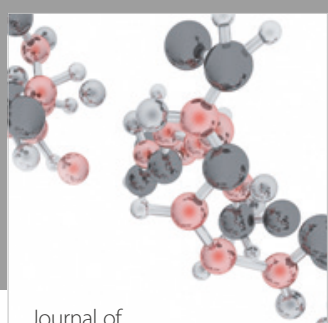

Analytical Methods

in Chemistry

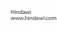

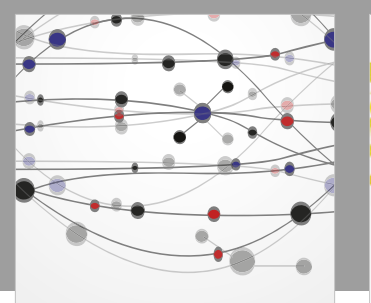

The Scientific World Journal

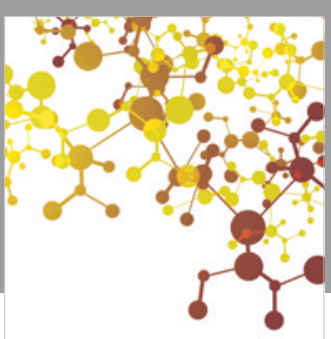

Journal of

Applied Chemistry
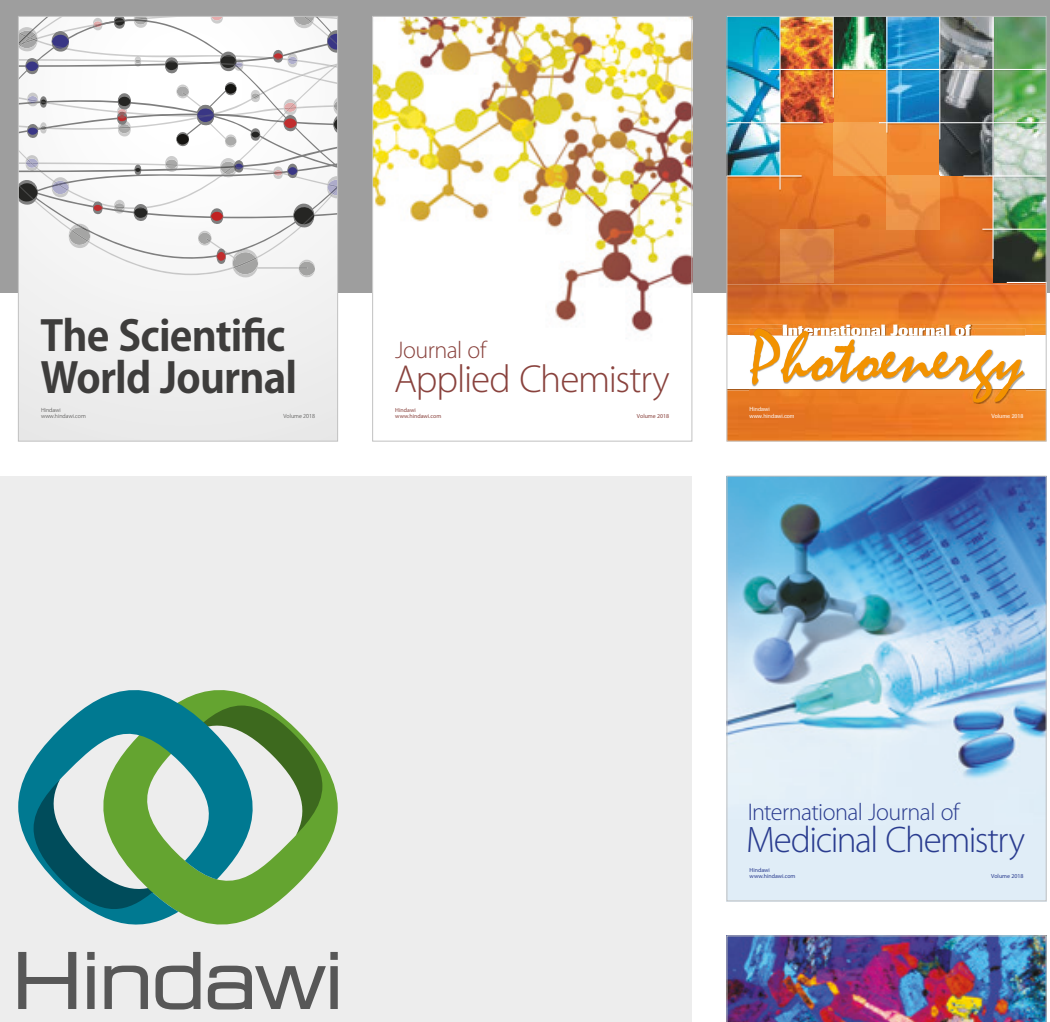

Submit your manuscripts at

www.hindawi.com
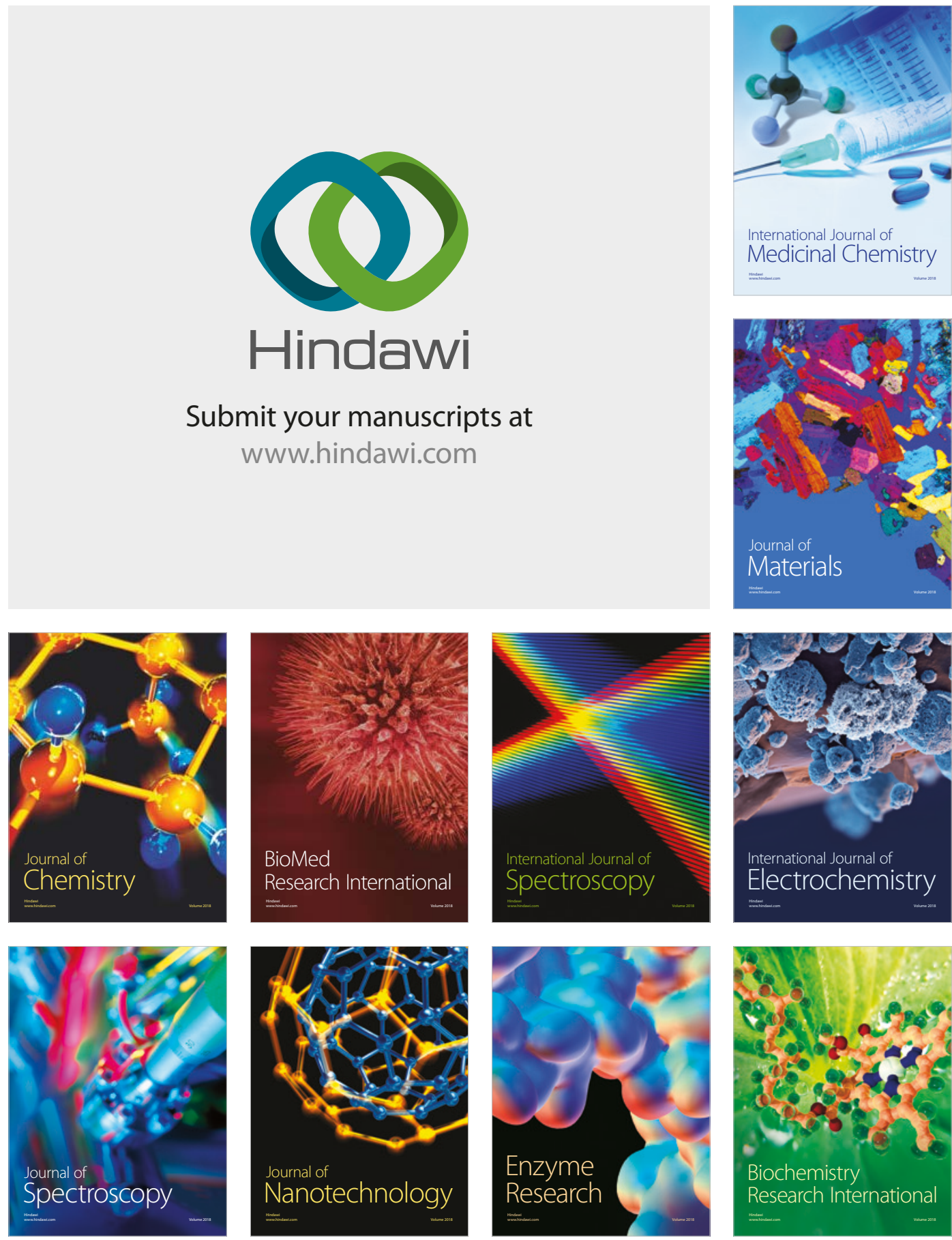
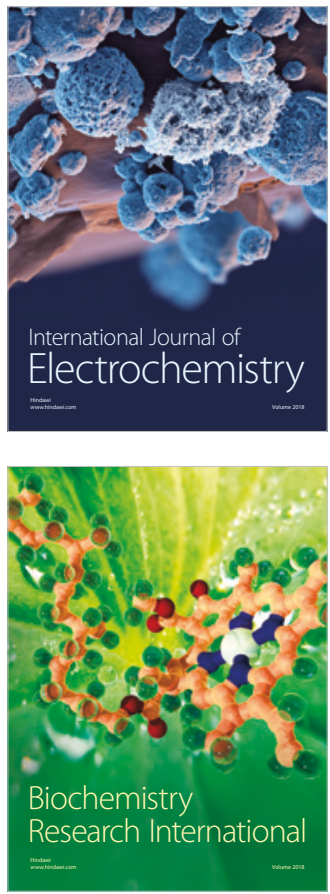